\title{
En sejrrig taber
}

\author{
Jan Jakob Floryan
}

\section{En fremragende biografi der viser Lenin som en klippefast fundamentalist, der tabte verdens- revolutionen}

Niels Erik Rosenfeldt: Lenin. En revolutionær fundamentalist. Høst $\mathcal{E}^{\circ}$ Søn, København 2008.

Niels Erik Rosenfeldts Lenin-biografi er fremragende. Lenin selv derimod fremstår som en temmelig usympatisk starut, kolerisk, påståelig og først og fremmest fundamentalistisk. Hør selv: "Han var efter hver ideologisk kolbøtte umiddelbart fuldt overbevist om, at netop han var landet på benene igen på den eneste rigtige måde. $\mathrm{Om}$ at han simpelthen havde ret i det essentielle. Objektivt set. Helt og holdent. Til enhver tid." Rosenfeldts karakteristik passer på enhver fundamentalist, og Lenin var altså en af de mere klippefaste. Han var antitesen til alt, hvad moderne ledelse præker. For Lenin var verden et skakbræt, og hvert træk enten en sejr eller et nederlag. Nulsumspil.

Hans tro på egen ret gjorde, at hans tolerance over for andres afvigende holdninger - og her taler vi ikke om 'klassefjender', men om nuancer i den bolsjevikiske lære - var minimal, og han drog straks ud i felten med sprogets groveste gloser for at bekæmpe dem. Hans arbejdsevne var formidabel, og han formåede at håndtere adskillige problemer og emner samtidig. Dertil kom en sær blanding af teoretisk skrivebordsarbejde og evne til at handle med stor beslutsomhed, som da han nærmest i strid med den øvrige kommunistiske ledelse (undtagen Trotskij) og sine egne teorier om samfundets udvikling gennemtvang Oktoberrevolutionen, uden i øvrigt selv at være aktiv i felten. Sådan gik det også på andre kritiske tidspunkter, hvor Lenin holdt sig til sit skrivebord, mens andre fór fra front til front.

Vi er vant til at se Lenin som en sejrherre, hvem det lykkedes at omkalfatre Rusland, lægge grunden til den sovjetiske stat og dens senere magt og erobringer. Men for Rosenfeldt var han en taber. Rosenfeldts perspektiv er nemlig verdensrevolu- 


\section{LITTERATUR}

tionen, som Lenin og de øvrige bolsjevikker ventede på og virkede for, og som skulle redde deres eget vakkelvorne styre i det tilbagestående Rusland. Nøglelandet her var Tyskland, og der blev brugt mange ressourcer på at fremme de røde tyskeres sag. Alle gange forgæves. Revolutionen forblev begrænset til Rusland.

Det får Rosenfeldt til at konkludere, at som verdensrevolutionær var Lenin en fiasko. Men uden at rokke ved hans historiske betydning, som en af dem der i højeste grad har påvirket det 20. århundredes udvikling. Rosenfeldt går nogle gange så vidt som til at tvivle, om der overhovedet ville have være en kommunistisk revolution i Rusland uden Lenin: Hvis Lenin under et forsøg på at undgå tsarens politi var gået gennem isen på Den Finske Bugt eller hvis han var blevet dræbt på sin cykel, da en fransk adelsmand påkørte ham i Paris. Men Lenin kom ingenting til, og verdenshistorien kunne fortsætte uhindret. Det er Rosenfeldts metode som historiker at afdække de samfundsmæssige præmisser for udviklingen, men i sidste ende at tillægge individerne en afgørende indflydelse på deres praktiske udmøntning.

\section{Privatlivet}

Bogen er først og fremmest en politisk biografi. Den kan læses som den russiske revolutions historie, og der er ikke for mange detaljer om Lenins privatliv. Forklaringen er nok, at han knap havde et. Det hele gik op i politisk aktivitet, lige siden han blev 'vakt', da hans ældre bror blev henrettet for meddelagtighed i et mordforsøg mod tsaren, og efter 1918 var det helt sket med privatlivet. Men noget får Rosenfeldt vredet ud af den tørre revolutionsteoretiker. Vi får at vide, at hans kone, Nadezjda Krupskaja, tog sig af madlavningen, for det kunne Lenin ikke håndtere. Under de mange eksilår levede han i München af mehlspeisen, mens de i London ikke kunne forlige sig med det engelske køkken overhovedet.

Og så var der den store udenomsægteskabelige romance med den russisk-franske kommunist Inessa Armand, der varede i adskillige år, men i øvrigt foregik med Nadezjda Krupskajas vidende. De tre optrådte ofte sammen, ligesom de to damer kunne slå hinanden følge. På det tidspunkt, skriver Rosenfeldt, var Lenins ægteskab forvandlet til et kammeratligt partnerskab, og i øvrigt mener han, at Lenin var ganske tilfreds med et hastigt kys mellem to teoretiske skrifter og altså ikke specielt krævende som elsker. Rosenfeldt snager ikke i spørgsmålet om, hvorfor der ikke var nogen børn i Lenins forhold, men holder sig lidt reserveret tilbage. Dog ikke uden humor og sågar sarkasme, som da han bemærker, at under forvisningen i Siberien måtte det nygifte par ansætte 
en hushjælp for at få tid til deres egne teoretiske aktiviteter til gavn for arbejderklassen.

\section{Lenin og Stauning}

Bogen er meget velskreven. Man mærker, at forfatteren har sproget i sin magt. Det er stilsikkert, let, til tider causerende, men altid præcist og varieret. At bogen er dansk og ikke oversat, giver også en anden form for bonus: Vi får at vide, hvad Lenin foretog sig under sine to besøg i Danmark (1907 og 1910), og hvad han tænkte om dansk politiks og især socialismes ledende skikkelse - Thorvald Stauning.

Og Lenin tænkte ikke godt om ham. Germanofil socialchauvinist var betegnelsen, og Stauning blev slået i hartkorn med andre revisionister og klasseforrædere som den tyske leder Karl Kautsky og øvrige socialdemokrater.

Stauning holdt sig heller ikke tilbage. Fra en senere kongres i Berlin skrev han, at han sjældent havde spildt så megen tid på vrøvl, især på grund af kommunisternes evige manøvreren og taktiske spil. Derimod var Lenin meget interesseret $\mathrm{i}$ og endda imponeret af den danske andelsbevægelse, som han studerede under sine ophold - teoretisk på Det Kgl. Bibliotek, for det hørte til hans ufravigelige vaner, at hvor han end kom, stod det lokale hovedbibliotek på programmet. Dog helst den ovale læsesal på British Mu- seum, der dels var datidens bedste, dels stedet hvor Marx havde siddet. Et håndgribeligt minde om Danmarksbesøgene er Lenin-statuen, der i dag kan ses på Arbejdermuseet i Rømersgade i København.

\section{Den sovjetiske terror}

Et afgørende spørgsmål, som Rosenfeldt gang på gang tager op, angår forholdet mellem Lenin og den sovjetiske terror, som den udfoldede sig i hans samtid og kulminerede under efterfølgeren Stalin. Her er Rosenfeldts konklusion klar: Det er ikke muligt at skelne mellem den 'gode Lenin' og den 'onde Stalin', ligesom man heller ikke kan adskille kommunismens humane og menneskekærlige principper fra den barbariske praksis. Det er der utallige belæg for. Dem nævner Rosenfeldt, men på intet tidspunkt følger han i den anden ledende danske ruslandsforsker Bent Jensens fodspor og foreholder, hvor og hvornår Vesten har svigtet, glemt eller set gennem fingrene med kommunismens ugerninger.

De konklusioner overlader Rosenfeldt til læseren selv, men sørger dog for, at vi får at vide, hvad Lenin mente om den humanistisk tænkende, borgerlige offentlighed, der uden at tilslutte sig bolsjevikkernes ideologi så den som et mere avanceret og moralsk rent bud på samfundets udvikling end kapitalismen. Vi kender dem som nyttige idioter, 


\section{LITTERATUR}

men Lenin havde et endnu mere rammende udtryk i sit fantastiske arsenal af skældsord: de døvstumme. Dem kunne man binde hvad som helst på ærmet, mente han - og havde ret når det gjaldt om at manipulere den progressive vestlige offentlighed.

"Man kan ikke lave en revolution uden henrettelser," udtalte Lenin, og henrettet blev der. Straks efter Oktoberrevolutionen blev der oprettet et hemmeligt sikkerhedsvæsen, Tjeka, der siden blandt andet blev kendt som KGB. Således kom Lenins stat, der i princippet skulle bygge på massernes selvorganisering, til at hvile på fire søjler: partiet, hæren, statsbureaukratiet og ikke mindst Tjekaen. Og sådan blev det frem til sovjetstatens endeligt lidt over 70 år senere.

Visse træk fortsætter endda den dag i dag, for eksempel den særlige paranoia over for udlandet. Under hungersnøden i begyndelsen af 1920 'erne blev de vestlige og især amerikanske hjælpeorgansationer nøje overvåget, kontrolleret og nærmest betragtet som spionreder. I dag har vestlige humanitære og forskningsmæssige institutioner det heller ikke let i Rusland, mens det er kriminelt for russiske græsrødder at modtage tilskud fra udlandet.

Et emne Rosenfeldt kun flygtigt berører i sit afsluttende afsnit er for- holdet mellem den kommunistiske og den nazistiske terror. Den tyske historiker Ernst Nolte skrev under den tyske historikerfejde i 1980'erne, at den kommunistiske terror var mere oprindelig end den nazistiske, og at den sidstnæunte derfor må ses i en vekselvirkning til den første.

Det havde været interessant at læse mere om det i Lenin-biografien og høre, om den sovjetiske terror simpelthen blev protypen på det 20 . århundredes statslige terrorvirksomhed.

Et andet lidt kritisk punkt er, at bogen er blottet for fodnoter. Kender man Niels Erik Rosenfeldt som forsker, vil man vide, at det er sket på læselighedens alter, men nogle steder ville man gerne have sat navn på en citeret kilde og ikke blot vide, at vedkommende stod Lenin nær.

Til gengæld er bogen gennemillustreret med velvalgte og velkommenterede fotografier, der fungerer som supplement til teksten. Et velskrevet, velkomponeret og klogt værk, der kun kan anbefales. Og man fristes til at forvente mere fra samme hånd: hvad med en dansk biografi af Lenins modspiller i 1917, den demokratiske politiker Kerenskij?

Jan Jakob Floryan er cand.scient.pol. og programmedarbejder ved $D R$. 